\title{
Sprawozdanie z „Dnia Informacji o Rekonstrukcjach Piersi BRA Day” w Łodzi
}

15 października 2014 roku w Wojewódzkim Szpitalu Specjalistycznym im. Mikołaja Kopernika w Łodzi po raz pierwszy w Polsce odbył się„Dzień Informacji o Rekonstrukcjach Piersi" w ramach międzynarodowej kampanii BRA Day (Breast Reconstruction Awareness Day).

Pomysłodawcą BRA Day jest kanadyjski chirurg plastyk dr Mitchell Brown. Zaniepokojony niewiedzą kobiet o możliwości wykonania rekonstrukcji piersi postanowił zorganizować akcję informacyjną, podejmującą tę problematykę. W 2011 roku w Toronto z jego inicjatywy po raz pierwszy zorganizowano BRA Day.

Dwa lata później BRA Day było zorganizowane już w 25 krajach, między innymi w Kanadzie, Stanach Zjednoczonych, Włoszech, Belgii i Niemczech.

Symbolem BRA Day jest różowa wstążka z zamkniętą pętlą, przypominającą znak nieskończoności (ryc. 1). Kształt ten ma symbolizować całościowy model leczenia chorych na raka piersi, obejmujący również rekonstrukcję piersi. Rekonstrukcja jest zabiegiem zamykającym pętlę w raku piersi.

Po raz pierwszy o BRA Day usłyszeliśmy w ubiegłym roku w Mediolanie na konferencji dotyczącej rekonstrukcji piersi, uczestnicząc w wykładzie dr. Mitchella Browna. Jego zaangażowanie i przekonanie o sensie propagowania wiedzy

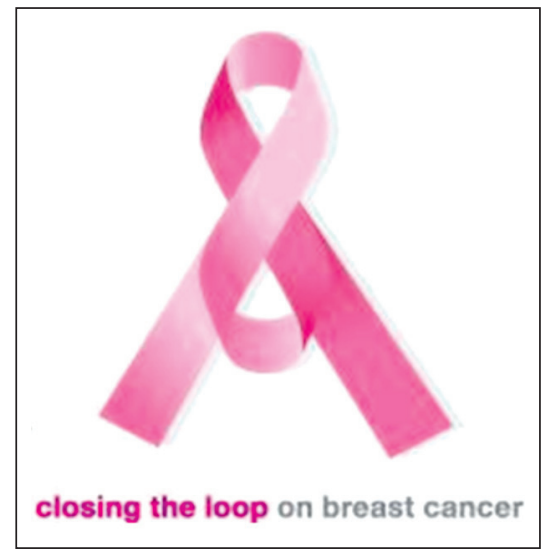

Rycina 1. Pętla różowej wstążki symbolizującej BRA Day (www.bra-day.com/, za zgodą) o rekonstrukcjach piersi u chorych na raka piersi zachęciły nas do zorganizowania podobnej akcji w naszym mieście. Kilka miesięcy później wystąpiliśmy o afiliację do biura BRA Day w Kanadzie. Dzięki temu uzyskaliśmy zarówno zgodę, jak i pomoc w zorganizowaniu akcji.

Mając wsparcie organizacji BRA Day, wraz z dyrektorem WSS im. M. Kopernika w Łodzi Panem Wojciechem Szrajberem zaczęliśmy przygotowania do obchodów BRA Day. Dużą cześć pracy wzięła na siebie Pani Beata Zdziennicka z Wojewódzkiego Ośrodka Koordynującego Populacyjny Program Wczesnego Wykrywania Raka Piersi w Łodzi. Aby uświetnić naszą akcję, poprosiliśmy o patronat honorowy Wojewodę Łódzkiego Panią Jolantę Chełmińską, Prezydenta Miasta Łodzi Panią Hannę Zdanowską, a ze strony Uniwersytetu Medycznego w Łodzi — prorektora ds. Organizacyjnych i Studenckich Pana Prof. dr. n. med. Radzisława Kordka.

Spotkanie wWSS im. Kopernika w Łodzi miało charakter edukacyjny i skierowane było w głównej mierze do kobiet po mastektomii i ich rodzin. Audytorium zapełniło się licznie zgromadzonymi pacjentkami leczonymi z powodu raka piersi, co w dużej mierze zawdzięczamy dobrej współpracy z Łódzkim Klubem Amazonek. Obecni byli również lekarze Ośrodka Onkologicznego w Łodzi, członkowie łódzkiego oddziału Polskiego Towarzystwa Onkologicznego oraz zaproszeni goście z innych szpitali w Łodzi, gdzie wykonywane są rekonstrukcje piersi. W spotkaniu wzięli również udział przedstawiciele Łódzkiego Oddziału Narodowego Funduszu Zdrowia, współorganizatorzy naszego przedsięwzięcia.

W pierwszej części spotkania wykład przedstawił dr $\mathrm{n}$. med. Piotr Pluta, który omówił założenia międzynarodowej akcji BRA Day, a następnie opisał różne techniki operacyjne rekonstrukcji piersi. Następnie swoje wystąpienie przedstawił prof. dr n. med. Arkadiusz Jeziorski, odpowiadając na pytanie "Dlaczego w XXI wieku ciągle wykonywane są mastektomie?". Kolejnym wykładowcą był dr n. med. Tomasz Huzarski, który w interesujący sposób odniósł się do genetycznych aspektów raka piersi w prezentacji pt. "Czy Angelina Jolie miała rację?". Ostatni wykład wygłosiła dr n. med. Aleksandra Ciałkowska-Rysz, konsultant krajowy ds. medycyny paliatywnej, omawiając możliwości leczenia bólu pooperacyjnego po rekonstrukcjach piersi. 
Po przerwie o swoich doświadczeniach opowiadały pacjentki, które poddały się rekonstrukcji piersi. Na sali w większości pozostały kobiety po mastektomii i ich rodziny. Ta część spotkania miała charakter bardzo emocjonalny. Należy podkreślić odwagę i otwartość pacjentek mówiących o swojej chorobie i przebiegu leczenia. W tej części padło również najwięcej pytań ze strony zebranych osób.

Organizując „Dzień Informacji o Rekonstrukcjach Piersi”, stawialiśmy sobie trzy podstawowe cele. Po pierwsze, chcieliśmy pokazać pacjentkom, w jaki sposób wykonujemy rekonstrukcje piersi, jakie są wskazania i przeciwwskazania do zabiegu, ale również jakie są realne możliwości wykonywanych zabiegów. Po drugie, chcieliśmy obalić mity związane z rekonstrukcjami piersi, biorąc tutaj za cel przeświadczenie o związanej z zabiegiem silnej bolesności. Po trzecie, chcieliśmy wykazać, że jest to zabieg dostępny dla większości pacjentek, wskazując oddziały chirurgiczne na terenie województwa łódzkiego, gdzie tego typu zabiegi są wykonywane. Podkreślaliśmy przy tym, że rekonstrukcje piersi u chorych na raka piersi są w pełni refundowane przez Narodowy Fundusz Zdrowia.

Z pewnością pierwszy „Dzień Informacji o Rekonstrukcjach Piersi" nie rozwiąże wszystkich wątpliwości pacjentek po mastektomii, dlatego też założyliśmy funpage BRA Day Polska na facebook.com, dzięki której osoby zainteresowane będą mogły uzyskać użyteczne informacje dotyczące rekonstrukcji piersi.

Biorąc pod uwagę, jak duże zainteresowanie wzbudziło nasze spotkanie wśród pacjentek, lekarzy, mediów oraz zaproszonych gości, w naszej ocenie istnieje głęboki sens w ponownym zorganizowaniu BRA Day w Łodzi w przyszłym roku. Mamy nadzieję, że nasze doświadczenia zachęcą Państwa do zorganizowania Dnia Informacji o Rekonstrukcjach Piersi w 2015 r. także w ośrodkach w innych miastach.

\section{Dr n. med. Piotr Pluta}

Klinika Chirurgii Onkologicznej UM w Łodzi

II Odział Chirurgii Onkologicznej, WSS im. M. Kopernika w Łodzi

ul. Pabianicka 62, 93-513 Łódź

e-mail:piotr.pluta@umed.lodz.pl 